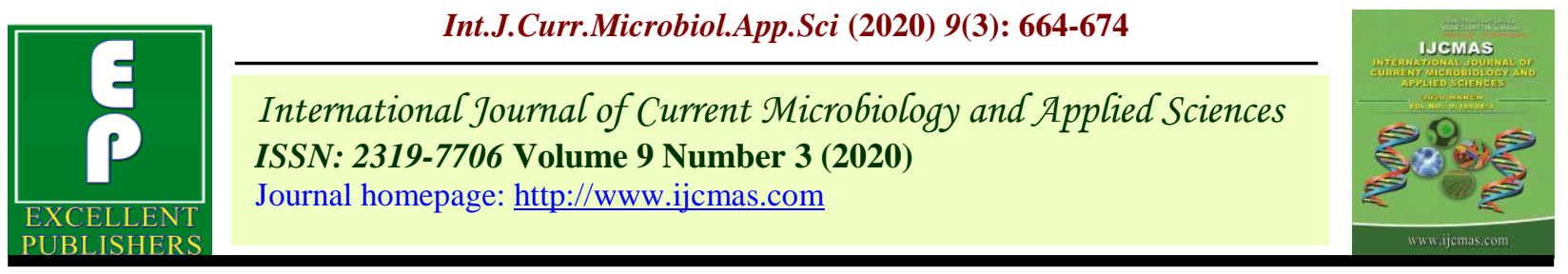

Original Research Article

https://doi.org/10.20546/ijcmas.2020.903.080

\title{
Influence of Packaging Materials and Storage Duration on Quality of Flower Strings of Polianthes tuberosa Linn. cv. Prajwal
}

\author{
Bijay Kumar Baidya $^{1 *}$ and Suhrita Chakrabarty ${ }^{2}$ \\ ${ }^{1}$ Department of Fruit Science and Horticulture Technology, College of Agriculture, \\ OUAT, Bhubaneswar, Odisha - 751003, India \\ ${ }^{2}$ Department of Post-Harvest Technology, Faculty of Horticulture, \\ AICRP on Floriculture, Bidhan Chandra Krishi Viswavidyalaya, \\ Mohanpur, Nadia, West Bengal-741252, India \\ *Corresponding author
}

\section{A B S T R A C T}

Keywords

Packaging materials, Shelf life, Acceptability, Quality, Storage and Tuberose strings.

Article Info

Accepted:

05 February 2020

Available Online:

10 March 2020
One of the major problems faced by the flower growers is lack of suitable packaging technology for local and distant markets. Therefore adequate packaging is required for enhancing their shelf life by retaining their attractiveness. Major objectives of this work was to study the effects of packaging materials and storage duration on flower quality, postharvest life \& consumers' acceptability of tuberose strings. In order to study the interaction effect of packaging materials i.e. containers (bamboo basket with newspaper lining, thermocol box and Corrugated Fibre Board (CFB) box) and storage conditions (S1 0day, S2-1day, S3-2day, S4-3day), tuberose flowers cv. Prajwal were harvested from the experimental plot early in the morning and tuberose strings of size 3 feet were made. It was observed that packaging significantly influenced weight loss, fresh weight, freshness of flowers throughout the storage period. In all storage containers, tuberose could be successfully stored for 1 day under ambient condition. Increase in storage duration significantly reduced shelf life of the strings along with their freshness, rotting and acceptability. However, considering shelf life (1.8 days), PLW (10.23\%), fresh flowers percentage (70.49\%) and acceptability (8.00), thermocol boxes were found as the better packaging material for tuberose strings, in which the strings could be stored for 1 day at ambient condition, followed by CFB Boxes (12"X10"X8" with holes).

\section{Introduction}

Flowers are one of the most important and unique gift of the nature to humanity. They are the adornments of the world with their valuable aesthetic, environmental, economic and medicinal properties. We know that flower have many uses in the life of human being. It is an integral part of lives in human society. The flower are mainly used for garland, veni, worship, table decoration, making bouquet, gajra, mandap decoration, bridal beds decoration as well as ceremonies and social functions. India has a long floriculture history and flowers are growing in an old enterprise. Reference to the flowers 
and garden are found in ancient Sanskrit classics like the Rig Veda, Ramayana, and Mahabharata. At the global level, at present flora business is around US\$ 176 billion, which is expanding day by day and with an annual average growth rate of 10.3 per cent and is expected to reach US\$250 billion by 2025 (Anonymous, 2015). Germany was the leading country in floriculture trade with $17.04 \%$ share, followed by USA $(10.57 \%)$ and Netherlands $(10 \%)$ while India falls on fifty second rank $(0.08 \%)$.

The estimated area under flower crops in India is about 634 thousand hectares and production of cut flower 528 thousand metric tonnes and loose flower is about 1656 thousand metric tonnes, respectively (Anonymous, 2015-2016). In West Bengal, flower crops area is about 25.63 thousand hectares and production of cut flower 68.2 thousand metric tonnes and loose flower is about 266.73 thousand metric tonnes, respectively (Anonymous, 2015-2016).

Among the flowers produced, tuberose (Polianthes tuberosa L.) a member of family Amaryllidaceae and originated from Mexico. It is one of the most important tropical ornamental bulbous flowering plants cultivated for production of long lasting flower spikes. It is popularly known as as Rajnigandha (Bengali, Hindi), Gul-e-chari (Urdu), Nishighandha (Marathi), Nishigandhi (Malayalam) and SemPangi (Tamil).Tuberose is commercially cultivated for cut and loose flower trade, and also it has long been cherished for aromatic oil extracted from its fragrant white flowers (Trueblood, 1973). Assam, Maharashtra, Gujarat, Haryana, Karnataka, Andhra Pradesh, Tamil Nadu, Uttar Pradesh, Uttrakhanda and Orissa are the major states where tuberose has become very popular. It is estimated that in India tuberose is commercially cultivated over 30,000 hactare area (Singh et al., 2010).
Tuberose flowers are highly perishable unlike other horticultural or agricultural crops. Due to the poor keeping quality, the post-harvest losses in floriculture are significantly higher than any other sector. It is estimated that there is about $20 \%$ loss of tuberose occur during market. Due to their extreme perishable nature proper treatment is required to maintain the quality of tuberose (Hardenburg, 1990). However, lack of knowledge regarding proper post-harvest handling is one of the limiting factors in expansion of the trade and export of tuberose.

Although there has been significant increase in the area, production and productivity of flower crops in the last two decades, there is an urgent need to minimize the huge postharvest losses in terms of the value of the produce which are estimated to be $30-40$ per cent of farm value. One of the major problems faced by the flower growers is lack of suitable packaging technology for local and distant markets. Whenever there is a delay in sending the flowers, the traders face heavy losses, because of the highly perishable nature of flowers which cannot be preserved for many days. Since the flowers retain their freshness only for a few days in ordinary packaging, any packaging technology focused on long term storage of flowers would definitely benefit the farmers as well as the traders.

Modified atmosphere packaging of fresh commodities is a successful technology for prolonging the post-harvest life during storage and marketing (Kader, 1986). One of the major benefits of modified atmosphere packaging (MAP) is the prevention or retardation of flower senescence and associated with physiological and biochemical changes (Sandhya, 2010).

Thus, the present investigation aimed to find out best packaging material for enhancing shelf life of tuberose flowers strings under 
West Bengal condition so that the flowers can be available to the end users (consumers, oil extractors, decorators making floral ornaments and likewise) for longer duration. Therefore, keeping in mind, the above discussed factors regarding the tuberose flowers strings, present investigation "Influence of Packaging Materials and Storage Duration on Quality of Flower Strings of Polianthes tuberosa Linn. cv. Prajwal" was planned.

\section{Materials and Methods}

The present investigation was undertaken under the department of Post-Harvest Technology of Horticultural crops under the Faculty of Horticulture during the year 201618. The laboratory work was carried out in laboratory of AICRP on Floriculture, Directorate of Research Complex, Kalyani, Bidhan Chandra KrishiViswavidyalaya, Mohanpur, Nadia, and West Bengal.The experimental details and techniques employed in the study are described as follows:

\section{Site of experiment}

Tuberose crop were grown in an experimental plot of Mondouri, Horticultural research station, Nadia, West Bengal. The post-harvest experiments were conducted under laboratory conditions at the Department of Post-Harvest Technology of Horticultural Crops, Faculty of Horticulture, Bidhan Chandra Krishi Viswavidyalaya Mohanpur; Nadia; West Bengal during 2016-2018.

For the experiment loose tuberose of $\mathrm{cv}$. Prajwal were collected from an experimental plot of Mondouri, Horticultural research station, Nadia, West Bengal. The experimental plot were well prepared by repeated tilling and application of organic manure $\left(@ 5 \mathrm{~kg} / \mathrm{m}^{2}\right.$ ) and inorganic fertilizer (N: P: K@ 100: 100: 150).

\section{Packaging materials}

In order to study the effect of packaging and storage on keeping quality of flowers strings of tuberose, fully developed unopened buds of tuberose loose flower cv. Prajwal was harvested from the experimental plot early in the morning. Tuberose strings of size 3 feet were made in the laboratory soon after harvesting.

In order to study the interaction effect of packaging (bamboo basket with newspaper lining, thermocol box and Corrugated Fibre Board (CFB) box) and storage conditions (S10day, S2-1day, S3-2day, S4-3day), the tuberose strings of size 3 feet was placed coiled inside the containers i.e. bamboo basket with newspaper lining, thermocol box and Corrugated Fibre Board (CFB) box. Where a small packet of ice wrapped with plastic was placed in the center of the bamboo basket and the thermocol box. The containers thereafter were closed tightly and stored for 0 , 1, 2, 3 day. After storage, the strings were hanged at ambient condition and observed for evaluation of their quality.

\section{Laboratory condition}

The temperature measured in Celsius scale and relative humidity, measured by hygrometer inside the laboratory during the experiments. Average light intensity inside the laboratory was 250 lux. Average temperature during the experiments was $31.74^{\circ} \mathrm{C}$ and relative humidity was $68.6 \%$.

\section{Variety}

Prajwal is single variety evolved through hybridization released from IIHR, Bangalore in 1990 (one among the low cost high yielding varieties developed by IIHR). It is the result of cross between 'Shringar' and 'Mexican Single'. It bears single type flowers 
on tall stiff spikes. The flower buds are slightly pinkish in colour while the flowers are pure white. The individual flowers are large in size, compared to 'Local Single'. It yields $15.5-18 \mathrm{t}$ loose flowers $/ \mathrm{ha} / \mathrm{yr}$. which is $20 \%$ more than 'Shringar' and also comparatively higher than other varieties. Prajwal is recommended both for loose and cut flower purpose. It shows early flowering (150-160 days) compared to many varieties, gives 3-4 spikes per clump and 35-45 florets/spike (Krishnamoorthy, 2014).This cultivar is best suited for loose flower, cut flower and perfumery industry).

\section{Observations recorded}

Fresh weight of flowers was measured using a weighing balance. Physiological loss in weight (PLW \%) and change in fresh weight (\%) and fresh flowers (\%) was calculated using the below formula

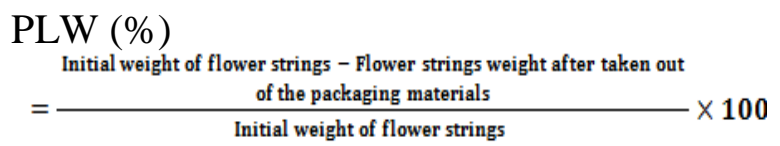

Change in fresh weight $(\%)$

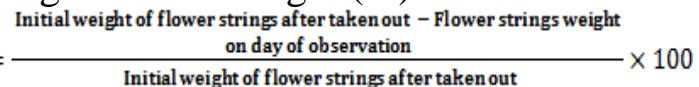

Fresh flowers (\%)

$=\frac{\text { No. of fresh flowers on the day of observation }}{\text { Total number of flowers }} \times 100$

Retention of colour were recorded daily and determined by visual observation using The Royal Horticulture Society (RHS) colour chart- mini by placing the colour chart above flowers. Acceptability was recorded daily by visual observations. It was based on 1-9 hedonic scale suggested by Ranganna (1997), score of 9 on hedonic scale determine the highest acceptability and score of 1 is consider as least acceptable. End of shelf life or vase life were concluded when the acceptability score fell below 5 (commercially unacceptable).

\section{Statistical analysis}

The experiment included three replications for each treatment. The design adopted was Factorial Completely Randomized Design (CRD) method used for calculating the variance of experiment. When two or more factors are tested simultaneously to see if they independently or actually interact with each other, the experiment is called factorial experiment (Mahalanobis, 1932).

\section{Results and Discussion}

\section{Shelf life in days}

The data pertaining to vase life of tuberose strings with different packaging materials are presented in Table 1. The shelf life of tuberose strings was significantly influenced with different packaging material during entire storage period. The data on shelf life of tuberose strings revealed that the maximum shelf life of 1.80 days was recorded in Thermocol boxes (C2S2) with 1 day storage duration followed by Corrugated Fiber Board boxes (C3S2) and Bamboo basket (C1S2) where shelf life of 1.50 days were recorded with 1day storage duration whereas minimum shelf life of 1 days was recorded in control i.e. without any packaging (C1S1, C2S1 and C3S1). Among the different treatments, flowers strings packed in thermocolboxes recorded comparatively more shelf life than flowers packed in CFB boxes sand bamboo basket for 1day storage duration. Duration of storage also plays an important role in shelf life of tuberose strings. Strings stored for 1day inside packaging showed maximum shelf life of 1.5 days after taken out of the packaging materials compare to 2 and 3 days storage duration. Thermocol packaging was also recommended by Senapati et al. (2016) 
in pre-cooled roses which are intended for air transport are frequently packed in polystyrene (thermocol) "caskets" to insulate them from warm outside temperatures. Ice is frequently added either as flake ice or as frozen gel-ice packages.

\section{Percent of fresh flowers}

The data pertaining percent of fresh flowers of tuberose strings with different packaging materials are presented in Table 1. The percent of fresh flowers of tuberose strings was significantly influenced with different packaging material during entire storage period. The data on percent of fresh flowers of tuberose strings revealed that the maximum percent of fresh flowers of $36.50 \%$ was recorded in Thermocol boxes $(\mathrm{C} 2 \mathrm{~S} 2)$ with 1 day storage duration followed Bamboo basket (C1S2) where percent of fresh flowers of $35.50 \%$ days were recorded with 1day storage duration. Among the different treatments, flowers strings packed in thermocol boxes recorded comparatively more percent of fresh flowers than flowers packed in CFB boxes and bamboo basket for 1day storage duration (Fig. 1). Duration of storage also plays an important role in percent of fresh flowers of tuberose strings. Strings stored for 1day inside packaging showed maximum percent of fresh flowers of $65.19 \%$ after taken out of the packaging materials compare to 2 and 3 days storage duration (Fig. 2). These results might be due to the modified atmosphere created by thermocol box by maintaining the moisture level optimum inside the packaging material.

\section{Percent of desiccated and rotting flowers}

The data pertaining percent of desiccated and rotting flowers of tuberose strings with different packaging materials are presented in Table 2. The percent of desiccated and rotting flowers of tuberose strings was significantly influenced with different packaging material during entire storage period. The data on percent of desiccated and rotting flowers of tuberose strings revealed that the maximum percent of desiccated flowers $(58.08 \%)$ was recorded in $\mathrm{CFB}$ boxes (C3S2) with 1 day storage duration followed Bamboo basket (C1S2) whereas maximum percent of rotting flowers $58.08 \%$ was recorded in thermocol boxes (C2S2) with 1 day storage duration. Among the different treatments, flowers strings packed in thermocol boxes recorded comparatively more percent of rotting flowers but less percent of desiccated flowers than flowers packed in CFB boxes and bamboo basket for 1day storage duration (Fig. 1).

Duration of storage also plays an important role in percent of desiccated flowers of tuberose strings. Strings stored for 3day inside packaging showed maximum percent of desiccated flowers of $66.67 \%$ after taken out of the packaging materials compare to 1 and 2 days storage duration (Fig. 2). Percent of desiccated flowers were maximum in case of CFB box followed by bamboo basket this might be due to the ventilation of packaging materials causing loss of moisture and flowers desiccated faster than thermocol packed flowers. In thermocol packaging desiccation was low due to its property of conserving moisture. However, this property of conserving moisture leads to maximum rotting of flowers.

\section{Changes in fresh weight after storage (\%) and Physiological loss of weight (PLW) during storage $(\%)$}

The data related to changes in fresh weight after storage $(\%)$ of tuberose strings with different packaging is presented in Table 1. The data was recorded after taking out garlands from the packaging materials and hanging the strings at ambient condition. The data recorded on the fresh weight of flowers significantly differed with different storage 
duration. On $1^{\text {st }}$ day after storage at ambient condition, least $(21.74 \%)$ change in fresh weight of tuberose strings was recorded in C3S4(CFB boxes stored for 3 days). On $2^{\text {nd }}$ day after storage, minimum $(26.18 \%)$ weight loss was observed in treatment $\mathrm{C} 2 \mathrm{~S} 4$ (thermocol boxes stored for 3 days).

The data pertaining percent of Physiological loss of weight (PLW) during storage of tuberose flower strings with different packaging materials are presented in Table 2 . The PLW\% during storage of tuberose flower strings was significantly influenced with different packaging material during entire storage period.

The data on PLW\% during storage of tuberose strings revealed that the maximum percent of PLW\% during storage $(56.20 \%)$ was recorded in bamboo basket boxes (C1S4) with 3 days storage duration followed CFB boxes (C3S4) i.e. $54.41 \%$ with 3 days storage duration.

Among the different packaging materials, flowers strings packed in CFB boxes $(30.11 \%)$ recorded comparatively more PLW\% during storage than flowers packed in thermocol boxes and bamboo basket for 3days storage duration.

Minimum PLW\% during storage was observed in thermocol box $(8 \%)$ when stored for 3 days. As far as duration of storage is concerned, minimum PLW\% during storage was recorded in 1 day storage i.e. $20.80 \%$ and maximum PLW\% during storage in 3 days storage i.e. $41.15 \%$. These results suggested that packaging material along with duration of storage had significant influence on changes in fresh weight after storage and PLW\% during storage of tuberose strings.

The flower strings packed in CFB boxes (C3S4 i.e. strings stored for 3 days inside
CFB box) recorded lowest percent of changes in fresh weight when stored for 1 day at ambient condition after taken out from packaging. But when stored for 2 day at ambient condition after taken out from packaging, thermocol box (C2S4 i.e. Strings stored for 3 days inside thermocol box) showed lowest percent of changes in fresh weight which might be due to no ventilation along with ice gel pack which might increases the moisture level inside the thermocol boxes.

Increase in moisture level also had detrimental effect as it increases rotting percentage of flowers in string. Considering the effect of containers then CFB box recorded lowest $(31.40 \%)$ percent of changes in fresh weight followed by bamboo basket (34.87\%) and highest in thermocol box $(35.07 \%)$ when stored for 1 day at ambient condition after taken out from packaging. But when stored for 2 day at ambient condition after taken out from packaging, CFB box recorded lowest (43.76\%) followed by thermocol box (49.27\%).

Similar findings were reported by Jawaharlal et al., (2012) that thermocol under gel-ice cold condition, was found to be highly suitable. Flowers in this package recorded shelf life of $42.88 \mathrm{~h}$, with a cost:benefit ratio of 1:2.5. Seddique et al., (1995) also observed that cold storage of roses at $4{ }^{\circ} \mathrm{C}$ in polystyrene boxes gave better results than storage under plastic film at the same temperature.

Polystyrene is considered as modified atmosphere packaging (MAP) because of its permeability to different gases. Polystyrene is chemically inert and possesses high degree of clarity. It is extensively used to wrap lettuce and tomatoes and is available as heat-shrink film (Sacharow and Griffin 1980). The less amount of gaseous permeability of Polystyrene may had resulted in retaining freshness in better way than that under CFB. 
Table.1 Shelf life (in days), physiological loss in weight (\%) after storage and changes in fresh weight after storage (during longevity period) of tuberose strings as affected by different packaging materials and storage duration

\begin{tabular}{|c|c|c|c|c|c|}
\hline \multirow[t]{2}{*}{ Treatments } & \multirow[t]{2}{*}{$\begin{array}{l}\text { Shelf life } \\
\text { (in days) }\end{array}$} & \multirow[t]{2}{*}{$\begin{array}{l}\text { PLW }(\%) \text { after } \\
\text { storage }\end{array}$} & \multicolumn{2}{|c|}{$\begin{array}{c}\text { Changes in fresh weight } \\
\text { after storage }(\%)\end{array}$} & \multirow{2}{*}{$\begin{array}{c}\text { Fresh } \\
\text { flower }(\%) \\
\text { 1st DAS }\end{array}$} \\
\hline & & & $\mathbf{1}^{\text {st }} \mathbf{D A S}$ & $2^{\text {nd }}$ DAS & \\
\hline \multicolumn{6}{|c|}{ Factor 1: Container } \\
\hline $\begin{array}{l}\text { C1(bamboo } \\
\text { basket) }\end{array}$ & 1.3 & $29.50(28.93)$ & 34.87 & 50.13 & 35.50 \\
\hline C2(thermocol) & 1.33 & $8.00(14.19)$ & 35.07 & 49.27 & 36.50 \\
\hline C3(CFB box) & 1.13 & $30.11(29.37)$ & 31.40 & 43.76 & 32.70 \\
\hline S.Em & 0.02 & 0.53 & 0.54 & 0.95 & 0.42 \\
\hline CD at $5 \%$ & 0.08 & 1.56 & 1.58 & 2.79 & 1.24 \\
\hline \multicolumn{6}{|c|}{ Factor 2: Duration } \\
\hline S1 (0 day) & 1.0 & NA & 35.27 & 52.01 & 49.03 \\
\hline S2 (1 day) & 1.5 & $20.80(26.64)$ & 37.19 & 59.56 & 65.19 \\
\hline S3 (2 day) & 1.33 & $28.18(31.00)$ & 38.09 & 47.82 & 25.38 \\
\hline S4 (3 day) & 1.17 & $41.15(39.02)$ & 24.57 & 31.51 & 0.00 \\
\hline S.Em & 0.03 & 0.61 & 0.62 & 1.10 & 0.49 \\
\hline CD at $5 \%$ & 0.09 & 1.81 & 1.82 & 3.22 & 1.43 \\
\hline \multicolumn{6}{|c|}{ Container X Duration } \\
\hline C1S1 & 1.0 & NA & 35.27 & 52.01 & 49.03 \\
\hline C1S2 & 1.5 & $24.48(29.56)$ & 36.20 & 58.35 & 63.00 \\
\hline C1S3 & 1.2 & $37.30(37.62)$ & 39.45 & 52.18 & 29.95 \\
\hline C1S4 & 1.5 & $56.20(48.55)$ & 28.57 & 37.99 & 0.00 \\
\hline C2S1 & 1.0 & NA & 35.27 & 52.01 & 49.03 \\
\hline C2S2 & 1.8 & $10.23(18.61)$ & 36.85 & 62.13 & 70.49 \\
\hline C2S3 & 1.5 & $8.91(17.14)$ & 44.75 & 56.77 & 26.50 \\
\hline C2S4 & 1.0 & $12.85(20.99)$ & 23.40 & 26.18 & 0.00 \\
\hline C3S1 & 1.0 & NA & 35.27 & 52.01 & 49.03 \\
\hline C3S2 & 1.5 & $27.69(31.73)$ & 38.53 & 58.19 & 62.07 \\
\hline C3S3 & 1.0 & $38.33(38.23)$ & 30.08 & 34.49 & 19.70 \\
\hline C3S4 & 1.0 & $54.41(47.51)$ & 21.74 & 30.36 & 0.00 \\
\hline S.Em & 0.05 & 1.06 & 1.08 & 1.90 & 0.84 \\
\hline CD at $5 \%$ & 0.17 & 3.13 & 4.65 & 5.58 & 2.48 \\
\hline
\end{tabular}

*NA - Not applicable, DAS - Days after storage, PLW (\%) - Arcsine transformation 
Table.2 Fresh flower (\%), rotting of flower (\%) and desiccated flower (\%) of tuberose strings as affected by different packaging materials

\begin{tabular}{|c|c|c|c|c|c|c|}
\hline \multirow[t]{2}{*}{ Treatments } & \multirow{2}{*}{$\begin{array}{c}\text { Acceptability } \\
\text { (1-9 hedonic } \\
\text { scale) } \\
\text { 1st DAS }\end{array}$} & \multicolumn{2}{|c|}{$\begin{array}{c}\text { Rotting of flower } \\
(\%)\end{array}$} & \multicolumn{2}{|c|}{$\begin{array}{c}\text { Desiccated flower } \\
(\%)\end{array}$} & \multirow{2}{*}{$\begin{array}{c}\text { Colour } \\
\text { (Initial - } \\
\text { RHS-115C } \\
\text { End of } \\
\text { Shelf life }\end{array}$} \\
\hline & & $1^{\text {st }}$ DAS & $2^{\text {nd }}$ DAS & $1^{\text {st }} \mathbf{D A S}$ & $2^{\text {nd }}$ DAS & \\
\hline \multicolumn{7}{|c|}{ Factor 1: Container } \\
\hline $\begin{array}{l}\text { C1(bamboo } \\
\text { basket) }\end{array}$ & 4.67 & 2.22 & 2.22 & 57.43 & 97.77 & NA \\
\hline C2(thermocol) & 4.83 & 41.77 & 57.76 & 16.76 & 42.23 & NA \\
\hline C3(CFB box) & 4.42 & 5.29 & 5.29 & 58.08 & 94.71 & NA \\
\hline S.Em & 0.05 & 0.52 & 0.63 & 0.81 & 0.63 & NA \\
\hline CD at $5 \%$ & 0.14 & 1.51 & 1.85 & 2.38 & 1.84 & NA \\
\hline \multicolumn{7}{|c|}{ Factor 2: Duration } \\
\hline S1 (0 day) & 5.17 & 8.89 & 8.89 & 34.07 & 91.11 & NA \\
\hline S2 (1 day) & 7.50 & 0.00 & 7.39 & 17.90 & 92.61 & NA \\
\hline S3 (2 day) & 3.72 & 23.48 & 37.42 & 57.72 & 62.57 & NA \\
\hline S4 (3 day) & 2.16 & 33.33 & 33.33 & 66.67 & 66.66 & NA \\
\hline S.Em & 0.06 & 0.60 & 0.73 & 0.94 & 0.72 & NA \\
\hline CD at $5 \%$ & 0.16 & 1.75 & 2.14 & 2.75 & 2.13 & NA \\
\hline \multicolumn{7}{|c|}{ Container X Duration } \\
\hline C1S1 & 5.17 & 8.89 & 8.89 & 34.07 & 91.11 & 155B \\
\hline C1S2 & 7.00 & 0.00 & 0.00 & 20.62 & 100 & 155B \\
\hline C1S3 & 4.00 & 0.00 & 0.00 & 75.04 & 100 & 155B \\
\hline C1S4 & 2.50 & 0.00 & 0.00 & 100 & 100 & $*$ \\
\hline C2S1 & 5.17 & 8.89 & 8.89 & 34.07 & 91.11 & $155 \mathrm{~B}$ \\
\hline C2S2 & 8.00 & 0.00 & 22.16 & 11.13 & 77.84 & $2 \mathrm{D}$ \\
\hline C2S3 & 4.17 & 58.19 & 100 & 21.83 & 0 & $2 \mathrm{D}$ \\
\hline C2S4 & 2.00 & 100 & 100 & 0.00 & 0 & $155 \mathrm{~A}$ \\
\hline C3S1 & 5.17 & 8.89 & 8.89 & 34.07 & 91.11 & 155B \\
\hline C3S2 & 7.50 & 0.00 & 0.00 & 21.94 & 100 & $115 \mathrm{~B}$ \\
\hline C3S3 & 3.00 & 12.26 & 12.26 & 76.29 & 87.73 & $2 \mathrm{D}$ \\
\hline C3S4 & 2.00 & 0.00 & 0.00 & 100 & 100 & $2 \mathrm{D}$ \\
\hline S.Em & 0.10 & 1.03 & 1.26 & 1.62 & 1.25 & NA \\
\hline CD at $5 \%$ & 0.28 & 3.03 & 3.70 & 4.76 & 3.69 & NA \\
\hline
\end{tabular}

*DAS - Days after storage

*NA - Not applicable, $(*)$ indicates - Black rotting colour 


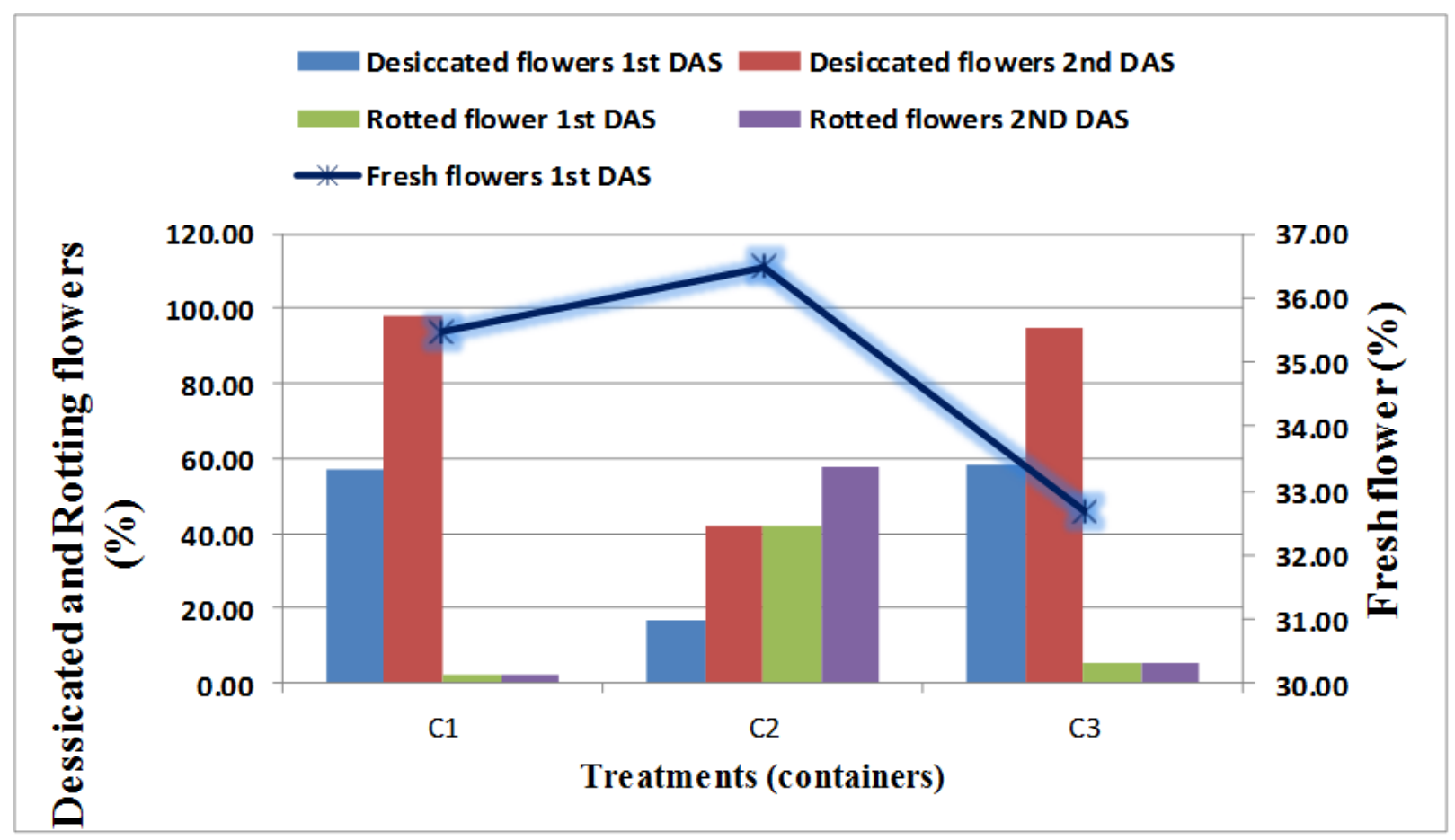

*C1-Bamboo basket, C2-Thermocol box, C3-Corrugated Fibre Board box

Fig.1 Percent of fresh, desiccated and rotting flowers of tuberose strings as influenced by different packaging materials

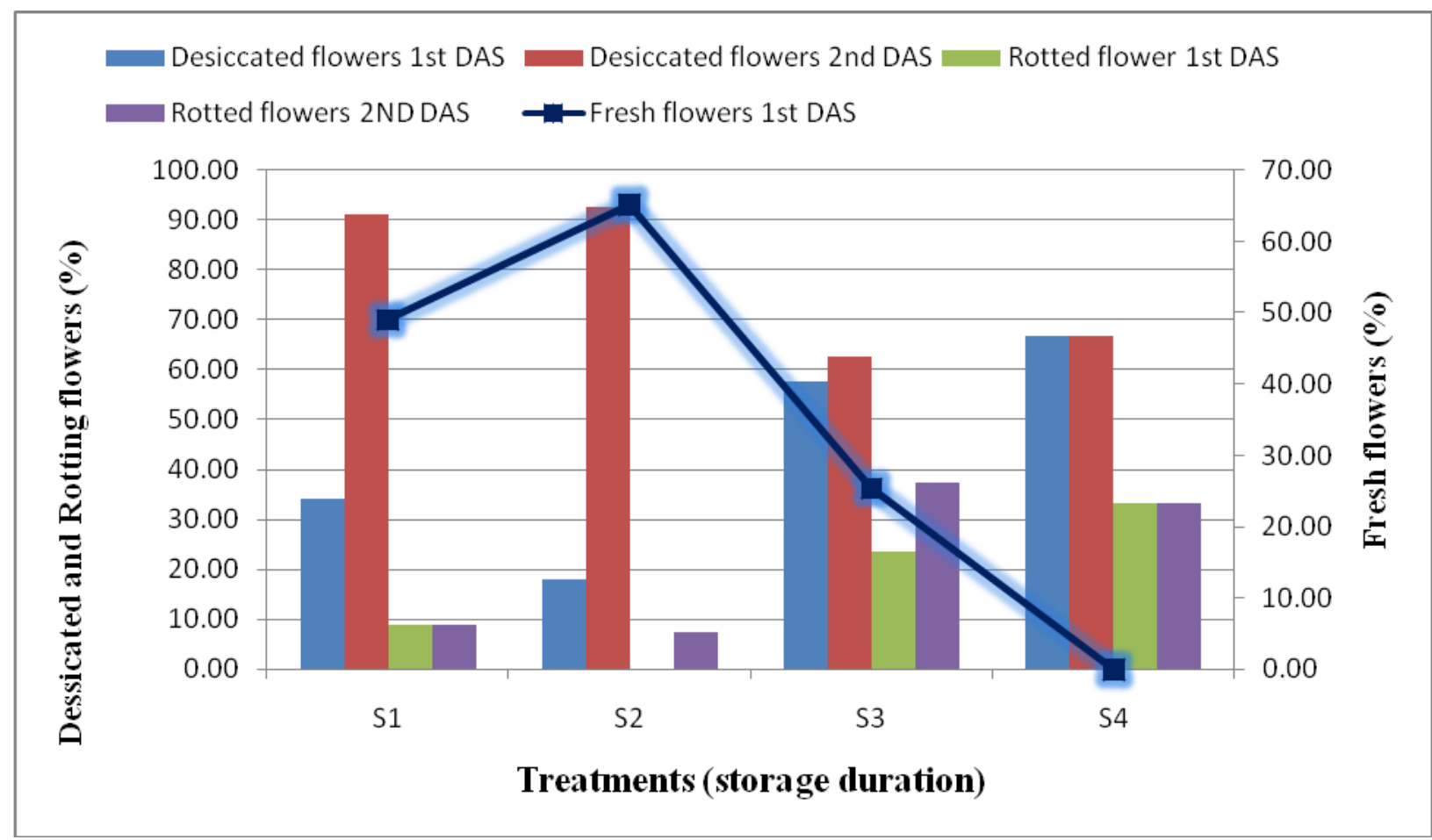

*Storage duration: S1-0day, S2-1day, S3-2day, S4-3day

Fig.2 Percent of fresh, desiccated and rotting flowers of tuberose strings as influenced by different duration of storage 


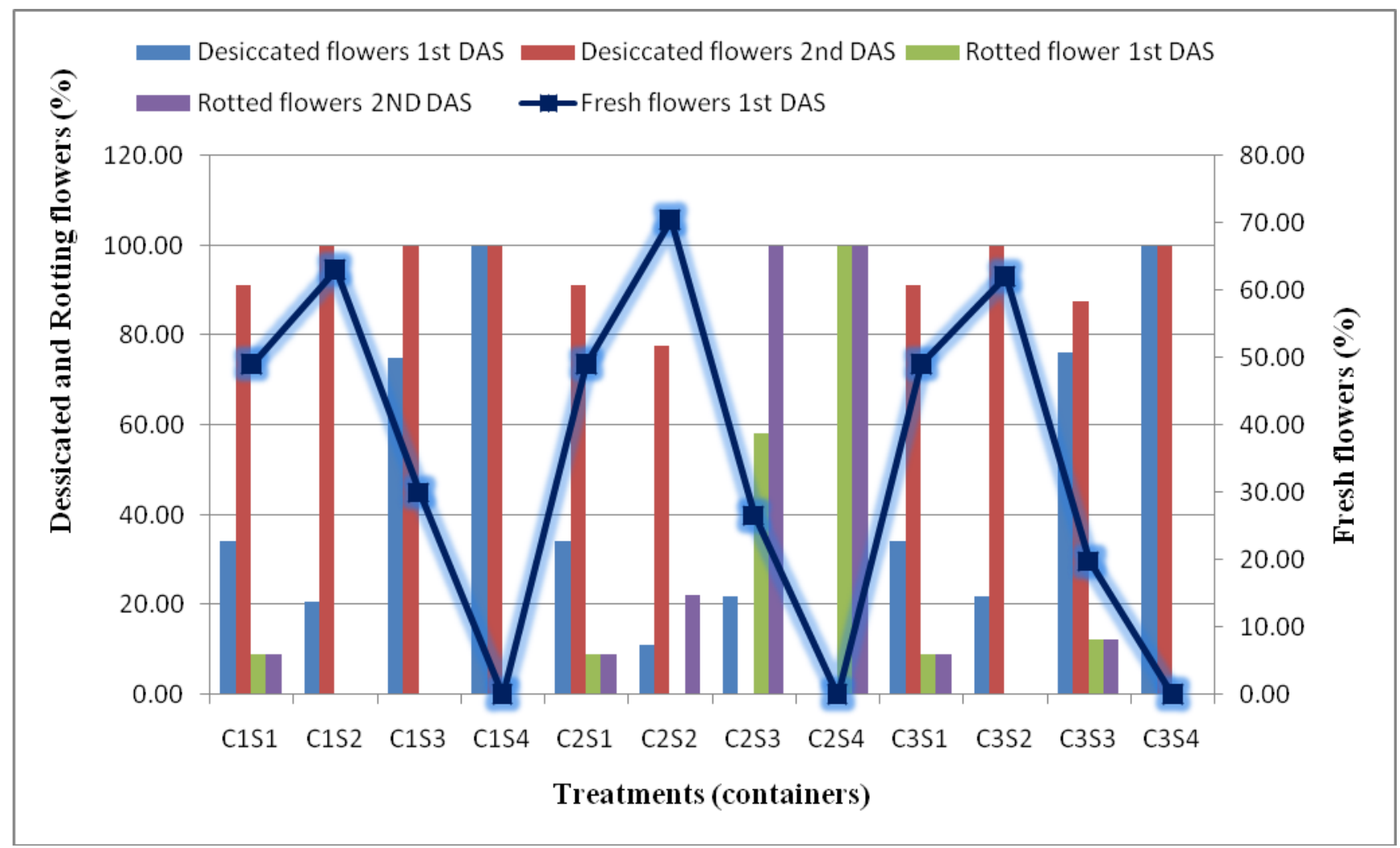

*Storage duration: S1-0day, S2-1day, S3-2day, S4-3day

*C1-Bamboo basket, C2-Thermocol box, C3-Corrugated Fibre Board box

Fig.3 Interaction effect of packaging materials and duration of storage on percent of fresh, desiccated and rotting flowers of tuberose strings

From the statistical analysis, we concluded that in all types of storage containers, tuberose could be successfully stored for 1 day only under ambient condition. Increase in storage duration significantly reduced shelf life of the garlands along with their freshness, rotting and acceptability.

However, considering shelf life (1.8 days), PLW (10.23\%), percentage of available fresh flowers (70.49\%) and acceptability (8.00), thermocol boxes were found as the better packaging material for tuberose strings, in which the strings could be stored for 1 day at ambient condition, followed by Bamboo basket and CFB Boxes (12"X10"X8" with holes). Thermocols are nothing but polystyrene which gave better results than storage under plastic film at the same temperature. Polystyrene is considered as modified atmosphere packaging (MAP) because of its permeability to different gases. The less amount of gaseous permeability of Polystyrene has resulted retaining freshness in better way than that under CFB. However, the same property helped in growth of microorganisms by conserving more moisture, which is exhibited by higher amount of rotting in the thermocol boxes.

Also, the cost and availability of thermocol boxes are an issue (almost three times costlier than bamboo baskets). Thus it may be concluded that tuberose flower strings stored in thermocol boxes for one day maintained good keeping quality and acceptability as compared to other two packaging materials. But, as an immediate alternative we can suggest the CFB against bamboo baskets considering its availability and cost. 


\section{References}

Anonymous. 2015.Global Horticulture Market Outlook 2015. http://www.prnewswire.com/newsreleases/global-horticulture-marketoutlook-2015-192285001.html

Anonymous. 2015-16. National Horticulture Board Data Base 2015-16. http//www.nhb.gov.in.

Hardenburg, R.E. 1990. The commercial storage of fruits, vegetables, and florist. and nursery stocks. USDA Agriculture Handbook.pp.66.

Jawaharlal, M., Thamavaiselvi, S.P. and Ganga, M. 2012.Standardization of export packaging technology for jasmine (Jasminum sambac Ait.) flowers.Acta Horticulture, 970: 81-91.

Kader, A.A. 1986. Modified atmosphere packaging (MAP) for long-term shipment of cut flowers. Acta Hortculturea.553: 631-634.

Krishnamoorthy, V. 2014.Assessment of tuberose (Polianthes tuberosa) varieties for growth and yield characters. The Asian journal of Horticulture, 9(2): 515-17.

Mahalanobis, P.C. 1932. Statistical notes for Agricultural workers. NO. 4. Rice and potato Experiment at Sriniketan. Indian Journal of Agricultural Science.2:694703.
Ranganna, S. 1997.Handbook of Analysis and Quality Control for Fruits and Vegetable Products.2nd ed., Tata Mac Graw Hill Publication Co., New Delhi.pp.112.

Sacharow, S. and Griffin J. R. C. 1980.The Evolution of Food Packaging.Principles of Food Packaging. 2nd ed. Westport, Conn.: AVI Publishing Co. Inc., 1-61

Sandhya.(2010). Effect of Pre- and Postharvest treatment on flower longevity of tuberose. Acta Horiculturea.482: 83-87.

Seddique, M., Mokhtari, M., Ait, Oubahou., A. and El Otmani, M. 1995. Effect of STS, calcium nitrate and cold storage on the vase life of two rose cultivars 'Royal Red' and 'Cocktail'.PostHarvest Physiology, Pathology and Technology for Horticultural Commodities: Recent Advances. 470479.

Senapati, A.K., Raj, D., Jain, R. and Patel.N.L. 2016.Advances in Packaging and Storage of Flowers. Commercial Horticulture. pp 473-488.

Singh, P.K., Kadam, G.B. and Jyoti, R. 2010. Production Manual on Tuberose (Polianthes tuberose L.) pp.1-2.

Trueblood, E.W.E. 1973. The tuberose (Polianthes tuberose L.)Economic Botany. pp.27:157.

\section{How to cite this article:}

Bijay Kumar Baidya and Suhrita Chakrabarty. 2020. Influence of Packaging Materials and Storage Duration on Quality of Flower Strings of Polianthes tuberosa Linn. cv. Prajwal. Int.J.Curr.Microbiol.App.Sci. 9(03): 664-674. doi: https://doi.org/10.20546/ijcmas.2020.903.080 